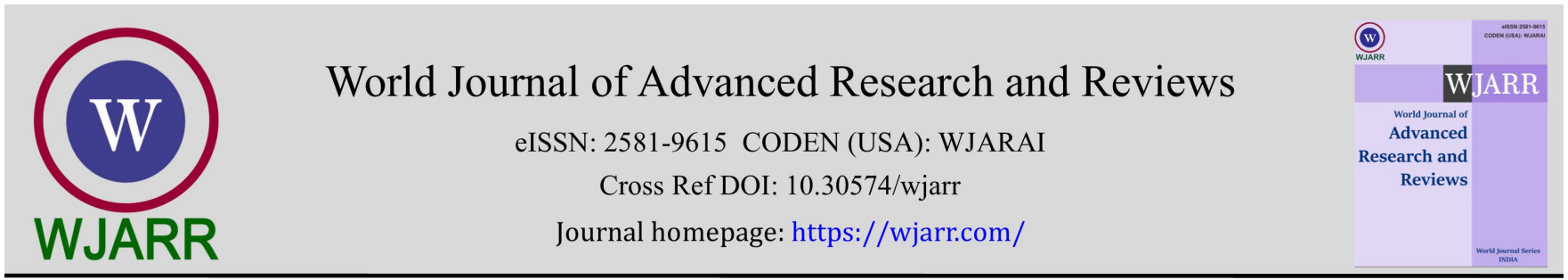

(RESEARCH ARTiClE)

Check for updates

\title{
Evaluation of the growth and egg-laying performance of quail (Coturnix Japonica) resulting from crosses of different strains of quail reared in Ivory Coast
}

\author{
Kelie Alain Rodrigue 1, Bouatene Djakalia 1.*, N’goran Evelyne Patricia Abo ${ }^{2}$ and Bohoua Louis Guichard ${ }^{1}$ \\ ${ }^{1}$ Department of Food Science and Technology, University Nangui Abrogoua, 02 BP 801 Abidjan 02, Côte d'Ivoire. \\ 2 National Center for Agronomic Research, 08 BP 881 Abidjan 08, Ivory Coast.
}

World Journal of Advanced Research and Reviews, 2021, 11(02), 380-389

Publication history: Received on 15 June 2021; revised on 01 August 2021; accepted on 03 August 2021

Article DOI: https://doi.org/10.30574/wjarr.2021.11.2.0331

\begin{abstract}
Quail weight and laying rate are very important parameters for quail breeders. This study aims to evaluate the growth and egg-laying performance of quails from different crosses in order to consider an improvement of performance through feeding. Thus, intra and inter crosses were made between the light strain and the heavy strain. To assess the growth and laying performance, it is used for each crossing result, 450 one day old quails and 120 females aged 42 days. These quails were reared under the same experimental conditions. The weight, the consumption and conversion index, the laying, the egg weight and mortality were recorded. The results show that the heavy strain has the highest weight (250.3g) followed by the mixed quail (216.9 - 218.8g). The light strain has the lowest weight (172.5g). Regarding the consumption indices, the heavy strain recorded the lowest index (3.24) followed by the mixed strain (3.52 - 3.59). As for the laying rate, the light strain obtained the highest rate $(75.7 \%)$ followed by the mixed quail $(68.7$ to $70.6 \%)$. The heavy strain has the lowest laying rate (64.2\%). In terms of conversion index, females of light strain recorded the best conversion index (3.8), followed by mixed quail (4.51 to 4.72). Regarding egg weight and mortality rate, no significant difference was observed between strains ( $p>0.05$ ). Considering its growth and laying performance the mixed strain is a promising strain which could be improved with feeding.
\end{abstract}

Keywords: Growth; Heavy; Laying; Light; Mixed strain; Quail

\section{Introduction}

The Japanese quail has experienced a considerable boom in the world in recent decades. It contributes to the diversity of poultry products. This species is of particular interest because of its hardiness, rapid growth and high egg production [1]. Quail is a luxury product in Ivory Coast. Generally, it is used in wedding ceremonies, baptism and during festivals.

In modern factory farming, quails are selected for the purpose of producing either eggs or meat but never both at the same time [2]. The consequence of this specialization is that on the one hand, in the meat production sectors, quails are selected on the sole criterion of their attitude to grow at high speed. These quails are sometimes slaughtered after only 35 days. On the other hand, in the egg production chains, male quail is not suitable for the production of fattening quail. As a result, they are gassed at birth. The gassing of males, even if permitted, is ecological nonsense [3].

Across the world, the heavy strain quail is used for meat production. They can weigh up to $300 \mathrm{~g}[4,5]$. While, the light strain is used for egg production. It can weigh between 160 and 200g [6]. In Ivory Coast, mainly include the slight strain and some rare times heavy strain on poultry farms. Thus, the light strain is used not only for egg production but also for meat production. This strain is not always appreciated by consumers due to its low weight. As for the heavy strain, its breeding is not popularized.

\footnotetext{
* Corresponding author: Bouatene Djakalia

Department of Food Science and Technology, University Nangui Abrogoua, 02 BP 801 Abidjan 02, Côte d'Ivoire.

Copyright (C) 2021 Author(s) retain the copyright of this article. This article is published under the terms of the Creative Commons Attribution Liscense 4.0.
} 
Like other poultry, genetic selection and diet are the best ways to improve the body weight and the egg production of the quail $[7,8,9]$.

In addition, some breeds are bred to produce both eggs and good quality meat. These breeds used for these two purposes are very valuable for breeders [10]. With the growing demand for products from quail, quail selected based on both the growth rate and egg production is necessary in poultry farms in Ivory Coast. Indeed, selection allows breeders to be more competitive on the market. The complementary effect between strains is another major argument crossing. It lies in the possibility of combining quails with contrasting aptitudes [7]. Thus, this present study aims to evaluate the growth performance (live weight, consumption index) and laying performance (laying rate, conversion index) of Japanese quail from different crosses in order to consider an improvement of performance through feeding

\section{Material and methods}

The study took place at the Labograin farm. Labograin is located in the town of Bingerville (Ivory Coast) in a dense forest area with a humid tropical climate with where there is a rainfall of $1653 \mathrm{~mm}$.

\subsection{Housing}

The animals were kept inside a modern livestock building which is built in the open air and oriented on an axis perpendicular to the winds. The building is characterized by a length of $20 \mathrm{~m}$, a width of $7 \mathrm{~m}$ and a height of $3.5 \mathrm{~m}$. At the entrance of the building, it is installed a footbath which served as disinfectant.

\subsection{Animals}

The animals used consist of heavy, light and mixed strain Japanese quails that are one day old. These quails are the result of intra and inter crosses between heavy and light strains of quail, which are 10 weeks old. There are 1200 breeding quails including 400 males and 800 females of heavy strain and light strain. The average weight of heavy strain females and males is $283.4 \pm 10.4 \mathrm{~g}$ and $255.7 \pm 7.6 \mathrm{~g}$, respectively. For females and males of light stock, the respective average weight is $198.6 \pm 5.9 \mathrm{~g}$ and $179.7 \pm 4.6 \mathrm{~g}$.

\subsection{Feeds}

The feeds distributed to quails are growth feeds and egg laying feeds. The growth feed is fed from 0 to 42 days. As for the laying feed, it is distributed after 43 days. These feeds are in floury form.

\subsection{Experimental arrangement}

The study was carried out in two phases. In the first phase, 1200 quails were divided into four batches of 300 quails. The first batch is a cross between 200 heavy strain females and 100 heavy strain males. The second batch is a cross of 200 females of light strain and 100 males of light strain. The third batch is a cross between 200 heavy strain females and 100 light strain males. This crossing is called mixed 1. As for the fourth batch, it is a cross between 200 females of light strain and 100 males of heavy strain. This crossing is called mixed 2 . In the second phase, the growth and egglaying performance of the quails, resulting from these different crosses, were evaluated.

\subsection{Technical monitoring}

The different batches of breeding stock were distributed so as to obtain a density of 40 quails $/ \mathrm{m}^{2}$. The lighting duration was maintained at 16 hours / day. The feed distributed to the animals is of the laying type. Water and feed were distributed ad libitum. For incubation, 800 eggs of each type of cross were used. The incubation temperature was maintained at $37.8^{\circ} \mathrm{C}$. Relative humidity was maintained at $60 \%$ during the first 14 days of incubation and $70 \%$ from day 15 to day 17.

After hatching, 450 quails from each cross were placed so as to obtain a density of 100 quails / $\mathrm{m}^{2}$ from 0 to 21 days and 50 quails $/ \mathrm{m}^{2}$ from 22 to 42 days. Then, their weight and their consumption index are determined each week. At 42 days, 120 females from each cross were distributed so as to obtain a density of 40 subjects $/ \mathrm{m}^{2}$. Next the laying performance were evaluated. Temperatures in the enclosure were $35^{\circ} \mathrm{C}$ for $0-7$ days, $32{ }^{\circ} \mathrm{C}$ for $8-21$ days and $26-30{ }^{\circ} \mathrm{C}$ after 22 days of age. The light program applied is 24 hours from 0 to 6 weeks and 16 hours in the laying phase. The animals received an anticoccidial between the $32^{\text {nd }}$ and the $35^{\text {th }}$ day. They were dewormed on the $50^{\text {th }}$ day. Feeds and water were distributed ad libitum. 


\subsection{Feed chemical analysis}

Feed rations were analyzed at the Central Analysis Laboratory of Nangui Abrogoua University and at the Laboratory of Abidjan Technical High School. The analysis consisted of determining the chemical composition of the feed supplied to quail. Thus, the dry matter, the protein and the crude fiber contents were determined according to the AOAC method [11]. The fat content was determined according to the AOAC method [12]. As for the determination of the mineral content, it was carried out according to the method of Houk et al. [13] and Duche et al. [14].

\subsection{Determination of growth performance and laying}

The quails are weighed every week at the same time, using a Tescoma brand electronic scale, with a capacity of $3 \mathrm{~kg}$ and a precision of $1 \mathrm{~g}$. The quantities of feed distributed and feeds refusals are also weighed daily. The eggs collected daily are also weighed using a Tescoma brand electronic scale, with a capacity of $300 \mathrm{~g}$ and precision of $0.1 \mathrm{~g}$.

\subsection{Determination of the average weight}

The average weight of the quail is the ratio between the sum of the weights of individuals in the same batch and the total number of individuals. It is determined according to the method of N'guessan et al. [6].

$$
\text { Average bodyweight }=\frac{\text { Sum of Weights }}{\text { total number of individuals }}
$$

\subsection{Determination of average daily gain}

It is determined according to the method of Hantanirina et al. [4]. The weekly weight measurements made it possible to calculate the average daily gain $(\mathrm{ADG})$ by making the ratio between the weight gain during a given period and the corresponding duration.

\subsection{Determination of average feed consumption}

The average feed consumption was determined by the method of Mabeki [15]. The daily weighing of the quantities of feed distributed and feed refusals made it possible to calculate the daily consumption of quails. The average feed consumption is determined as follows:

$$
\text { Average feed consumption }=\frac{\text { Feed distributed }- \text { Feed refusals }}{\text { Number of individuals }}
$$

\subsection{Determination of the consumption index and conversion index}

The consumption and conversion index are determined according to the method of Hantanirina et al. [4]. The consumption index results from the ratio between the amounts of feed ingested at a given period and the weight gain at the same period. While, the conversion index results from the ratio between the amount of feed ingested (g) and the weight of the eggs (g) corresponding to the same period.

\subsection{Determination of the age of sexual maturity}

The age of sexual maturity is determined according to the method of Ould et al [16]. This age corresponds to the age of the quail when the first egg was laid.

\subsection{Determination of average egg weight}

Average egg weight is calculated using the formula of Ould et al. [16]. Weighing the eggs daily yielded the average egg weight for the week. It is determined as follows:

$$
\text { Average egg weight }(\mathrm{g})=\frac{\text { Total weight of eggs collected }(\mathrm{g})}{\text { Total number of eggs collected }}
$$

\subsection{Determination of the egg-laying rate}

It is determined according to the method of Hantanirina et al. [4]. It is calculated daily from the following formula:

$$
\text { Laying rate }(\%)=\frac{\text { Number of eggs } \mathrm{x} 100}{\text { Number of females }}
$$




\subsection{Determination of mortality rate and viability}

The mortality rate and viability are determined according to the method of Mabeki [15]. The mortality rate is the ratio between the number of dead animals and the initial total number of animals multiplied by 100 . As for viability, it is determined as follows:

$$
\text { Viability }(\%)=100-\text { Mortality rate }
$$

\subsection{Statistical analysis of data}

Descriptive statistics (determination of the mean, standard deviation and coefficients of variation) were used. The DUNCAN test was applied to compare the means at the $5 \%$ threshold using the STATISTICA 7.1 software.

\section{Results}

\subsection{Chemical composition of feeds}

The chemical composition of the feed used during the study is shown in Table 1. The protein and metabolizable energy contents of the ration distributed during the growth period and during the laying period are high. They vary respectively from $2960 \mathrm{Kcal} / \mathrm{Kg}$ to $3000 \mathrm{Kcal} / \mathrm{Kg}$ and 19 to 25\%. The feeds are also rich in calcium. The calcium content is $1.19 \%$ for the growth feed and $3.07 \%$ for the laying feed.

Table 1 Chemical composition of feeds

\begin{tabular}{|l|c|c|}
\hline Parameters & Growth feed & Laying feed \\
\hline Dry matter (\%) & $88.34 \pm 0.31$ & $89 \pm 0.25$ \\
\hline Metabolizable energy (kcal / kg) & $3008.2 \pm 21.60$ & $2965.6 \pm 18.50$ \\
\hline Total nitrogenous matter (\%) & $25.69 \pm 0.30$ & $19.58 \pm 0.60$ \\
\hline Fat materials (\%) & $3.97 \pm 0.15$ & $4.1 \pm 0.21$ \\
\hline Crude fiber (\%) & $4.3 \pm 0.63$ & $6.7 \pm 1.10$ \\
\hline Calcium (\%) & $1.19 \pm 0.52$ & $3.07 \pm 0.38$ \\
\hline Phosphorus (\%) & $0.65 \pm 0.00$ & $1.1 \pm 0.20$ \\
\hline
\end{tabular}

\subsection{Performance during growth period}

\subsubsection{Average weight without distinction of all sexes}

The table 2 shows the weekly evolution of the average weight of quails. At the hatching, the weight of the heavy strain is $10.8 \pm 0.4 \mathrm{~g}$ compared to $7.68 \pm 0.3 \mathrm{~g}$ for the light strain.

Table 2 Evolution of the average weight (g) versus strain

\begin{tabular}{|c|c|c|c|c|}
\hline \multirow{2}{*}{ Age (week) } & \multicolumn{4}{|c|}{ Quail strain } \\
\cline { 2 - 5 } & Heavy & Light & Mixed 1 & Mixed 2 \\
\hline 0 (hatching) & $10.80 \pm 0.4^{\mathrm{a}}$ & $7.68 \pm 0.3^{\mathrm{b}}$ & $8.21 \pm 0.5^{\mathrm{b}}$ & $8.23 \pm 0.6^{\mathrm{b}}$ \\
\hline 1 & $37.90 \pm 2.4^{\mathrm{a}}$ & $25.70 \pm 2^{\mathrm{c}}$ & $2907 \pm 3.1^{\mathrm{b}}$ & $30.20 \pm 3.2^{\mathrm{b}}$ \\
\hline 2 & $79.60 \pm 3.9^{\mathrm{a}}$ & $55.00 \pm 2.6^{\mathrm{c}}$ & $61.80 \pm 3.2^{\mathrm{b}}$ & $62.00 \pm 3.9^{\mathrm{b}}$ \\
\hline 3 & $126.80 \pm 5.9^{\mathrm{a}}$ & $87.6 \pm 4.4^{\mathrm{c}}$ & $105.70 \pm 6.7^{\mathrm{b}}$ & $104.30 \pm 6.8^{\mathrm{b}}$ \\
\hline 4 & $175.40 \pm 7.3^{\mathrm{a}}$ & $124.00 \pm 5.6^{\mathrm{c}}$ & $149.50 \pm 9.3^{\mathrm{b}}$ & $150.10 \pm 8.3^{\mathrm{b}}$ \\
\hline 5 & $216.60 \pm 6.1^{\mathrm{a}}$ & $153.10 \pm 6.3^{\mathrm{c}}$ & $186.00 \pm 12.9^{\mathrm{b}}$ & $187.10 \pm 13.1^{\mathrm{b}}$ \\
\hline 6 & $250.30 \pm 7.4^{\mathrm{a}}$ & $172.50 \pm 6.7^{\mathrm{c}}$ & $216.90 \pm 13.2^{\mathrm{b}}$ & $218.80 \pm 14.5^{\mathrm{b}}$ \\
\hline
\end{tabular}


The weight of the mixed strain 1 ( $\%$ heavy X $\sigma^{\top}$ light) and the mixed strain 2 ( $\%$ light $X \sigma^{x}$ heavy) are respectively $8.21 \pm$ $0.5 \mathrm{~g}$ and $8.23 \pm 0.6 \mathrm{~g}$. All of these weights gradually increase with the age of the birds. At 6 weeks, the weight of the heavy strain, the mixed strain 1 and the mixed strain 2 respectively reached $250.3 \mathrm{~g} ; 216.9 \mathrm{~g}$ and $218.8 \mathrm{~g}$. The light strain recorded the lowest weight (172.5g). Statically, the weight of the heavy strain (250.3g) is higher than that of the other strains $(\mathrm{p}<0.05)$. Compared to the weight of the light strain, the mixed strains showed significantly higher values $(\mathrm{p}<0.05)$.

\subsection{Average weights by sex and strain}

Table 3 shows the weekly change of the average weight of the quails by sex and strain. Whatever the strain, the weight of females is significantly higher than that of males ( $\mathrm{P}<0.05)$. This difference of weight is noticeable from the third week of age for the light strain and the mixed strain 1 . For the heavy strain and the mixed strain 2 , the females presented a higher weight respectively from weeks 5 and 4 . At 6 weeks, the weight difference between females and males is $15.7 \mathrm{~g}$ and $27.5 \mathrm{~g}$ respectively for the heavy strain and the light strain. That of the mixed 1 and mixed 2 strains is respectively $35.9 \mathrm{~g}$ and $17.4 \mathrm{~g}$. However, the weights of females and males of the heavy strain are higher than those of females and males of other strains. The quails of the light strain recorded the lowest weights.

Table 3 Evolution of the average weight (g) according to the strain and the sex

\begin{tabular}{|c|c|c|c|c|c|c|c|c|}
\hline \multirow{3}{*}{$\begin{array}{l}\text { Age } \\
\text { (week) }\end{array}$} & \multicolumn{8}{|c|}{ Strains of quail } \\
\hline & \multicolumn{2}{|c|}{ Heavy } & \multicolumn{2}{|c|}{ Light } & \multicolumn{2}{|c|}{ Mixed 1} & \multicolumn{2}{|c|}{ Mixed 2} \\
\hline & q & $0^{\pi}$ & q & $0^{x}$ & q & $0^{x}$ & 우요 & $\sigma^{x}$ \\
\hline 3 & $130.4 \pm 4 a$ & $123.2 \pm 3^{a}$ & $90.4 \pm 2^{\mathrm{a}}$ & $84.8 \pm 2^{\mathrm{b}}$ & $110.6 \pm 4^{\mathrm{a}}$ & $100.8 \pm 2^{\mathrm{b}}$ & $106.2 \pm 3^{\mathrm{a}}$ & $102.4 \pm 4^{\mathrm{a}}$ \\
\hline 4 & $179.0 \pm 4^{a}$ & $171.8 \pm 3^{a}$ & $124.2 \pm 1^{\mathrm{a}}$ & $115.9 \pm 1^{b}$ & $158.0 \pm 4^{a}$ & $140.9 \pm 3^{b}$ & $153.5 \pm 4^{a}$ & $146.8 \pm 2^{b}$ \\
\hline 5 & $220.6 \pm 4^{a}$ & $212.6 \pm 2^{b}$ & $158.8 \pm 1^{a}$ & $147,4 \pm 3^{b}$ & $197.4 \pm 3^{a}$ & $174.5 \pm 2^{b}$ & $191.0 \pm 4^{a}$ & $183.2 \pm 4 b$ \\
\hline 6 & $258.2 \pm 5^{\mathrm{a}}$ & $242.5 \pm 3^{b}$ & $186.2 \pm 2^{a}$ & $158.7 \pm 3^{b}$ & $234.9 \pm 6^{a}$ & $199.0 \pm 3^{b}$ & $227.5 \pm 5^{a}$ & $210.1 \pm 9^{b}$ \\
\hline
\end{tabular}

For each strain, the same letter on the same line means that there is no significant difference between the live weight of females and males, at the threshold of 0.05 .

\subsection{Average Daily Gain, Feed consumption, Consumption index and Mortality rate according to strain}

The average daily gain (ADG), the death rate, the feed consumption and the consumption index are presented in Table 4. It appears from this table that the Average Daily Gain of the period going from 22 to 42 days is higher than that ranging from 0 to 21 days. The average daily gain (ADG) of the heavy strain is significantly higher compared to the other strains $(\mathrm{p}<0.05)$. Regarding the mortality rate, it is higher during the 0-21-day phase compared to the 22-42-day phase. However, no statistical difference was revealed between the mortality rate of the different strains ( $p>0.05)$. For all strains, feed consumption and consumption index increased with the age of the quails. It is also noted that the consumption of the heavy strain and of the mixed strains are clearly greater than that of the light strain $(\mathrm{p}<0.05)$. The lowest consumption index value was obtained with the heavy strain, followed by the mixed strains. Statically, the consumption index of the heavy strain is lower than that of the other strains $(\mathrm{p}<0.05)$.

Table 4 Average Daily Gain, Food Consumption, Consumption Index and mortality rate according to strain of quail

\begin{tabular}{|l|c|c|l|l|c|}
\hline \multirow{2}{*}{ Parameters } & \multirow{2}{*}{ Periods (days) } & \multicolumn{4}{|c|}{ Strain of quail } \\
\cline { 3 - 6 } & & Heavy & Light & Mixed 1 & Mixed 2 \\
\hline \multirow{3}{*}{ Average Daily Gain (g / day) } & $0-21$ & $5.52 \pm 0.2^{\mathrm{a}}$ & $3.81 \pm 0.1^{\mathrm{c}}$ & $4.64 \pm 0.1^{\mathrm{b}}$ & $4.57 \pm 0.3^{\mathrm{b}}$ \\
\cline { 2 - 6 } & $22-42$ & $5.88 \pm 0.1^{\mathrm{a}}$ & $4.04 \pm 0.2^{\mathrm{c}}$ & $5.3 \pm 0.2^{\mathrm{b}}$ & $5.45 \pm 0.1^{\mathrm{b}}$ \\
\cline { 2 - 6 } & $0-42$ & $5.70 \pm 0.1^{\mathrm{a}}$ & $3.92 \pm 0.1^{\mathrm{c}}$ & $4.97 \pm 0.2^{\mathrm{b}}$ & $5.01 \pm 0.0^{\mathrm{b}}$ \\
\hline \multirow{3}{*}{ Total consumption feed } & $0-21$ & $272.90 \pm 6.1^{\mathrm{a}}$ & $230.50 \pm 5.2^{\mathrm{b}}$ & $260.10 \pm 7.2^{\mathrm{a}}$ & $260.60 \pm 5.9^{\mathrm{a}}$ \\
\cline { 2 - 6 } & $22-42$ & $504.50 \pm 11.2^{\mathrm{a}}$ & $432.50 \pm 7.5^{\mathrm{b}}$ & $499.00 \pm 7.3^{\mathrm{a}}$ & $493.40 \pm 8.4^{\mathrm{a}}$ \\
\cline { 2 - 6 } & $0-42$ & $777.40 \pm 10.5^{\mathrm{c}}$ & $663.00 \pm 8.7^{\mathrm{b}}$ & $759.10 \pm 11.4^{\mathrm{b}}$ & $754.00 \pm 13.2^{\mathrm{b}}$ \\
\hline
\end{tabular}




\begin{tabular}{|l|c|c|c|c|c|}
\hline \multirow{3}{*}{ Consumption index } & $0-21$ & $2.26 \pm 0.1^{\mathrm{a}}$ & $2.78 \pm 0.0^{\mathrm{c}}$ & $2.57 \pm 0.0^{\mathrm{b}}$ & $2.59 \pm 0.0^{\mathrm{b}}$ \\
\cline { 2 - 6 } & $22-42$ & $4.21 \pm 0.0^{\mathrm{a}}$ & $5.53 \pm 0.0^{\mathrm{c}}$ & $4.61 \pm 0.1^{\mathrm{b}}$ & $4.44 \pm 0.0^{\mathrm{b}}$ \\
\cline { 2 - 6 } & $0-42$ & $3.24 \pm 0.0^{\mathrm{a}}$ & $4.15 \pm 0.0^{\mathrm{a}}$ & $3.59 \pm 0^{\mathrm{b}}$ & $3.52 \pm 0.0^{\mathrm{b}}$ \\
\hline \multirow{3}{*}{ Mortality rate (\%) } & $0-21$ & $3.56 \pm 1.0^{\mathrm{a}}$ & $3.11 \pm 0.8^{\mathrm{a}}$ & $3.78 \pm 1.7^{\mathrm{a}}$ & $3.56 \pm 0.4^{\mathrm{a}}$ \\
\cline { 2 - 6 } & $22-42$ & $0.67 \pm 0.0^{\mathrm{a}}$ & $0.33 \pm 0.0^{\mathrm{a}}$ & $0.67 \pm 0,0^{\mathrm{a}}$ & $0,33 \pm 0,0^{\mathrm{a}}$ \\
\cline { 2 - 6 } & $0-42$ & $4.22 \pm 0.5^{\mathrm{a}}$ & $3.44 \pm 0.4^{\mathrm{a}}$ & $4.44 \pm 0.7^{\mathrm{a}}$ & $3.89 \pm 0.5^{\mathrm{a}}$ \\
\hline
\end{tabular}

The same letter on the same line means that there is no significant difference between the values at the threshold of 0.05 .

\subsection{Performance during the laying}

\subsubsection{Sexual maturity, body weights at the start of egg laying and viability of female}

Sexual maturity, the average body weight at the start of egg laying and the viability of females are shown in Table 5. The attainment of sexual maturity (onset of lay) is earlier for light strain females (37 days) than those of other strains. At the start of laying, the body weight of the light strain females is $169.1 \mathrm{~g}$ against $259.4 \mathrm{~g}$ for the heavy strain. That of mixed strain 1 and mixed strain 2 is $236.4 \mathrm{~g}$ and $227.5 \mathrm{~g}$ respectively. Regarding the viability of females, no significant difference was observed between strains.

Table 5 Viability, age and body weight of females at the start of laying

\begin{tabular}{|l|c|c|c|c|}
\hline \multirow{2}{*}{ Parameters } & \multicolumn{4}{|c|}{ Strain of quail } \\
\cline { 2 - 5 } & Heavy & Light & Mixed 1 & Mixed 2 \\
\hline Age at onset of lay (days) & 43 & 37 & 43 & 42 \\
\hline Weight at the start of laying (g) & $259.4 \pm 6.1^{\mathrm{a}}$ & $169.1 \pm 5.8^{\mathrm{c}}$ & $236.4 \pm 7.8^{\mathrm{b}}$ & $227.5 \pm 8.9^{\mathrm{b}}$ \\
\hline Viability (\%) & $98.3 \pm 1.4^{\mathrm{a}}$ & $100 \pm 0.0^{\mathrm{a}}$ & $100 \pm 0.0^{\mathrm{a}}$ & $99.2 \pm 1.4^{\mathrm{a}}$ \\
\hline
\end{tabular}

The same letter on the same line means that there is no significant difference between the strains at the threshold of 0.05 .

\section{6. laying rate}

The evolution of the laying rate is illustrated by Figure 1 . The laying rate gradually increases and then decreases for all the strains. At the start of laying, the light strain has a higher laying rate compared to other strains. Overall, from 7 to 18 weeks, the highest laying rate is observed with the light strain $(75.7 \pm 1.4 \%)$ followed by mixed strain $2(70.6 \pm 1 \%)$ and mixed strain $1(68.7 \pm 1.2 \%)$. The heavy strain recorded the lowest rate $(64.2 \pm 0.8 \%)$.

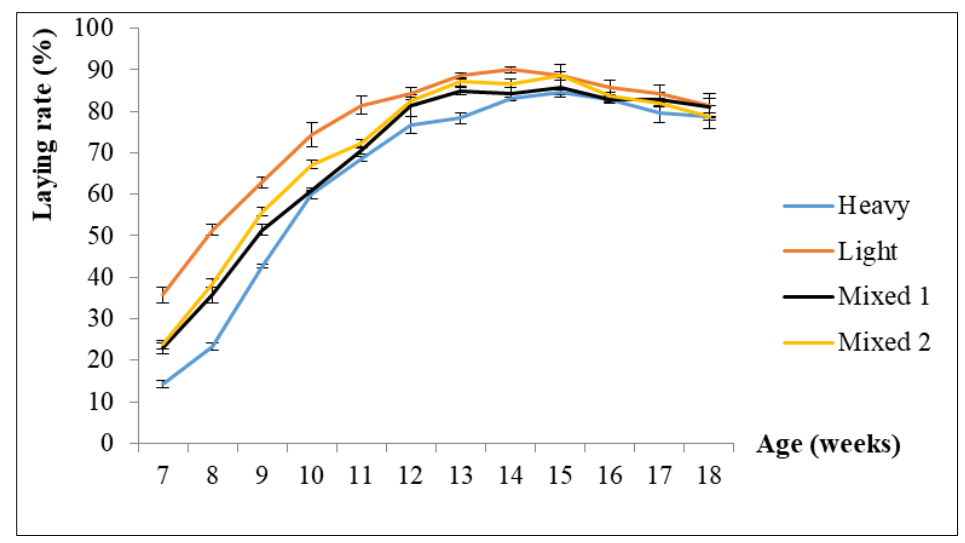

Figure 1 Evolution of the spawning rate depending on the strain

\subsection{Egg weight and conversion index}

Average egg weight and female conversion index are shown in Table 6. For all the strains, the egg weight increases with the age of females. Statically, no difference is revealed between the weights of the eggs of the different strains at the $5 \%$ 
level. As for the conversion index of females, the lowest index is obtained with the light strain $(\mathrm{p}<0.05)$. Compared to the conversion index of the heavy strain females, the mixed strains showed low values $(\mathrm{p}<0.05)$.

Table 6 Egg weight and female conversion index depending on the strain

\begin{tabular}{|l|c|l|l|l|l|}
\hline \multirow{2}{*}{ Parameters } & \multirow{2}{*}{ Period (weeks) } & \multicolumn{4}{|c|}{ Strain of quail } \\
\cline { 3 - 6 } & & Heavy & Light & Mixed 1 & Mixed 2 \\
\hline \multirow{2}{*}{ Average egg weight (g) } & 7 & $9.03 \pm 0.06^{\mathrm{b}}$ & $9.26 \pm 0.07^{\mathrm{a}}$ & $9.19 \pm 0.02^{\mathrm{a}}$ & $9.24 \pm 0.03^{\mathrm{a}}$ \\
\cline { 2 - 6 } & 18 & $13.12 \pm 0.06^{\mathrm{a}}$ & $13.11 \pm 0.35^{\mathrm{a}}$ & $12.81 \pm 0.33^{\mathrm{a}}$ & $12.77 \pm 0.21^{\mathrm{a}}$ \\
\cline { 2 - 6 } & $7-18$ & $11.82 \pm 0.05^{\mathrm{a}}$ & $11.84 \pm 0.05^{\mathrm{a}}$ & $11.71 \pm 0.14^{\mathrm{a}}$ & $11.77 \pm 0.04^{\mathrm{a}}$ \\
\hline Average conversion index & $7-18$ & $6.18 \pm 0.06^{\mathrm{a}}$ & $3.8 \pm 0.02^{\mathrm{c}}$ & $4.72 \pm 0.04^{\mathrm{b}}$ & $4.51 \pm 0.03^{\mathrm{b}}$ \\
\hline
\end{tabular}

\section{Discussion}

The average weight of quail is different from one strain to another strain since hatching. This variation of weight could be attributed to the difference of the genetic makeup of these strains. These results are confirmed by Jatoi et al. [5] and [17]. Indeed, these authors showed a significant variation of the weight with four strains of quail at 42 days. The results obtained for the light strain are similar to those of N'guessan et al [6]. These authors obtained a hatching weight of 7.46g. For heavy strain quails, the weight is similar to that obtained by Berrama [18] and Razafimandimby [19] who found respective weights of $11.86 \mathrm{~g}$ and $11 \mathrm{~g}$. As for the mixed strains, the weights are similar to those obtained by Ashok et al. [20] with an average of $8.53 \mathrm{~g}$.

Whatever the strain considered, the weight of females is significantly higher than that of males. These results are confirmed by Ojedapo \& Amao [21]. Unlike almost all other domestic avian species, sexual dimorphism of quail favors the female. This superiority is generally manifested from the 2 nd week of age [22]. Sometimes the weight of the female is significantly higher than that of the male from the 4th week of age [23].

The average daily gain of the heavy strain quail tested is higher than that of the other strains. Generally, the average daily gain of quail ranges from 3 to $4 \mathrm{~g}$ per day $[9,6]$. For heavy strain quail, it can reach $6 \mathrm{~g}$ per day [24, 25].

Feed consumption of all strains increased with the age of the birds. This can be explained by the fact that, the increase of the weight of quails is accompanied by that of consumption. Feed consumption is also different from one strain to another. Compared to the light strain, the feed consumption of the heavy strain and the mixed strains is significantly higher. In fact, these two strains presented a significantly higher weight than that of the light strain. Thus, the amount of feed consumed by the quail would depend on age, strain and also body weight. This significant variation of feed consumption is reported with different strains of quail by Akram et al. [26]. Also, the feed consumption of quails depends on the chemical composition of the feed. Indeed, the rate of protein recommended for feed is 24 to $27 \%$ during the growth period [9]. However, when the protein level of the feed is below the required standard, the quails consume more feed to meet their protein requirements.

The consumption index is different from one strain to another. The variation of the consumption index due to the strain is also observed by Jatoi et al. [5]. In the present study, the consumption index is better for the heavy strain quail. The consumption index is better when it is low. These results are confirmed by Siyadati et al. [24]. According to these authors, the consumption index of heavy strain quail at 45 days is 2.44 with a feed containing an energy of $2900 \mathrm{Kcal} /$ $\mathrm{Kg}$ and a protein rate of 24 to $27 \%$ [24]. According to Dowarah \& Sethi [25], the consumption index of heavy strain quail is 3 for a feed containing an energy of $3000 \mathrm{Kcal} / \mathrm{Kg}$ and $27 \%$ of protein. By count, the consumption index of light strain quail is 5.18 with a feed containing an energy of $3200 \mathrm{Kcal} / \mathrm{Kg}$ and 26\% of protein [24]. According to Dahloum et al. [27], the body weight and consumption index of quail are influenced by their genetic lineage. Also, interactions between the genetic line and feed exist. This is what sometimes leads to observations of opposite performances. The consumption index is also a function of the protein level and the metabolizable energy of the feed. The index decreases with increasing levels of these nutrients of the feed $[28,9]$.

Regarding egg-laying performance, the sexual maturity of light strain quail is earlier than that of other strains. The sexual maturity of the Japanese quail is influenced by its genetic lineage and the body weight. According to Bensalah [2], 
the birds that have more body weight at sexual maturity perform better. Whereas, those with low body weight experience delayed sexual maturity and decreased performance. In this present study, although the light strain have a lower weight than the other strains, its maturity is earlier. The genetic line of this strain is believed to be the source of early spawning. In this study, the sexual maturity of heavy strain and mixed strains are similar to those observed by Bensalah [2] at 42 days of age with a diet containing $20 \%$ faba treated. During the production period, the difference in the evolution of the laying rate of the different strains is due to the fact that not all the females have the same sexual maturity. The drop in the laying rate observed after peak spawning can be explained physiologically by a slowdown of follicular activity. The high laying rate at the start of spawning of the light strain can be explained by its earlier sexual maturity. Indeed, for quail, the laying rate increases rapidly from the first egg laid and reaches the peak between the $3^{\text {rd }}$ and $5^{\text {th }}$ week $[4,2]$. Over the entire trial period ( 7 to 18 weeks), the highest laying rate is observed with the light strain (75.7\%), followed by mixed strains (68.7 to 70,6\%) and the heavy strain (64.2\%). Thus, egg production of quail depends on the strain. Like the hen, egg production of quail depends on its environment and its diet [29]. According to Karousa et al. [30], the laying rate is between $46.6 \%$ and $63.5 \%$ for the quail of 6 weeks old conducted in captivity. In another study, Moula et al. [31], reported a laying rate of $74.44 \%$ with quails between 7 and 44 weeks of age. Higher production (82 to 89.36\%) is observed by Hassan [32], Abdel-Azeem [33] and Marques et al. [35] during a period going from the $6^{\text {th }}$ to the $14^{\text {th }}$ week.

The conversion index is significantly higher with the heavy strain (6.18) compared to the light strain (3.8) and the mixed strains (4.51 to 4.72). The conversion ratio of the slight strain tested is similar to that of Agboola et al. [8] with values between 3.72 and 3.96. According to Sangilimadan et al. [29], the conversion index of females between 6 and 30 weeks of age is between 3.28 and 4.66. These values are similar to those of mixed quail and light strain quail. The conversion index of the quail also depends on the metabolizable energy and the protein level of the feed. The quail fed with 3000 $\mathrm{kcal} / \mathrm{kg}$ of metabolizable energy has a lower conversion index than those fed with 3100 and $3200 \mathrm{kcal} / \mathrm{kg}$ of metabolizable energy. A level of $20 \%$ protein is necessary to obtain an optimal conversion index [8].

One of the most important parameters for consumers is the weight of eggs. The weight of the eggs is several times smaller than that of a standard chicken egg (60-63g) [36]. In the present study, no statistical difference is revealed between the eggs weights of the strains tested. However, the weight of the eggs is significantly influenced by the age of the quail. The weight of the eggs at the start of laying with a value of $9.03 \mathrm{~g}$ reached $13.12 \mathrm{~g}$ at 18 weeks. The average weight of the eggs produced by the quails tested varies between 11.71 and 11,82g. These weights are similar to those obtained by Berrama et al. [18], Sangilimadan et al. [28] and Moula et al. [31], respectively 11.8; 12.4 and 12.3g. Higher weights, ranging from 11.80 to $13.38 \mathrm{~g}$, have been observed between 6 and 20 weeks of age. This is confirmed with the work of Abdel-Azeem [33] and Çabuk et al. [37].

In this study, the death rate is identical from one strain to another. The recorded mortality rate (3.11 to $3.78 \%)$ for the period from 0 to 21 days is higher than that of 22 to 42 days $(0.33$ to $0.67 \%)$. Generally, the mortality rate of the different strains is between $3.44 \%$ and $4.44 \%$. These rates are less than $5 \%$. Regarding the viability of females, no significant difference is also observed between strains. The results of the present study are observed by Dahloum et al. [27]. According to these authors, the mortality rate during the period of quail growth is $4.36 \%$. Also, these authors have shown that quail mortality is particularly higher between 1 and 21 days than the period ranging from 22 to 42 days

\section{Conclusion}

This study made it possible to evaluate the production performance of quails from different crosses of quail strains. It appears from the study that the heavy strain from the cross between intra heavy strains has the best growth performance. While, light strain quail from the cross between intra light strains has the best egg laying performance. The crosses between the light strain and the heavy strain resulted in a promising strain. These mixed quails have a weight of 216.9 to $218.8 \mathrm{~g}$ and a laying rate of $68.7 \%$ to $70.6 \%$. An improvement of the performance of this strain could make it a useful strain for both meat and egg production. The performance of this strain could be improved by feeding.

\section{Compliance with ethical standards}

\section{Acknowledgments}

We would like to thank the company Labograin Africa for facilitating the incubation of the eggs of the quails. We also thank University of Nangui Abrogoua for the chemical analysis. 


\section{Disclosure of conflict of interest}

All authors have read, understand and agreed to the submission guidelines, policies and submission declaration of the journal. All authors have approved the manuscript as submitted.

\section{Statement of ethical approval}

The study was approved by the Institutional Animal Ethics Committee of University Nangui Abrogoua of Ivory Coast.

\section{References}

[1] Siyadati SA, Irani M, Ghavidel Z. Effect of varying dietary energy to protein ratio on productive performance and carcass characteristics of Japanese quail. Annals of Biological Research. 2011; 2(1): 149-155.

[2] Bensalah A. Effects of some feed formulas on the zootechnical performances and the biochemical profile of Japanese quail. Master's thesis in Veterinary Sciences, University of the Brothers Nentouri Constantine, Algeria. 2016; 231.

[3] Maurer V. Two-purpose hen breeds: potentials and limitations. BIO Actualities.ch, Switzerland. 2014; 8.

[4] Hantanirina HI, Rabearimisa RN, Rakotozandiny JN. Domestication of quail in Madagascar: case of Japanese quail. Akon'ny Ala. 2013; 32: 24-33.

[5] Jatoi A. S, Mehmood S, Hussain J, Ishaq HM, Abbas Y, Akram M. Comparison of six-week growth performance in four different strains of Japanese quail (Coturnix coturnix japonica). Sarhad Journal of Agriculture. 2015; 31 (1): 59-64.

[6] N'Guessan AR, Soro D, Traore B. Substitution of fish meal by pigeon Pea (Cajanus cajn) flour and Moringa oleifera leaves (Moringa oleifera) in quail feed: Effects on zootechnical and sanitary performances. International Journal of Science and Research. 2018; 7(10): 1588-1594.

[7] Coudurier B. Constraints and opportunities for organizing selection in the pig and poultry sectors. INRA Animal Production. 2011; 24 (4): 307-322.

[8] Agboola AF, Omidiwura BRO, Ologbosere EY, Iyayi EA. Determination of crude protein and metabolisable energy of Japanese quail (Coturnix coturnix japonica) during laying period. Journal of World's Poultry Research. 2016; 6 (3): 131-138.

[9] Omidiwura BR, O Odu O, Agboola AF, Akinbola DD, Iyayi EA. Crude protein and energy requirements of Japanese quail (Coturnix japonica) during rearing period. Journal of World's Poultry Research. 2016; 6 (2): 99-104.

[10] Mesenbourg T, Potok NA, Lamas EJ. New Hampshire: Summary Population and Housing Characteristics 2010. Department of Commerce Economics and Statistics Administration, Washington. 2012; 129.

[11] AOAC. Official Methods of Analysis, 15th Edition, Association of Official Analytical Chemistry, Washington DC. 1990.

[12] AOAC. Official Methods of Analysis, $16^{\text {th }}$ Edition, Association of Official Analytical Chemistry, Washington DC. International Arlington VA. 1995. 250.

[13] Houk RS, Fassl VA, Flesch GD, Svec HJ, Gray AL, Taylor CE. inductively coupled argon plasma as an ion source for mass spectrometic determination of trace elements. Analytical Chemistry. 1980; 52: 2283-2289.

[14] Duche A, Lefevre P, Sabroux V, Berdon D, Bernard G. The techniques of feed analysis applied to CIRAD - EMVT. 1992; 79.

[15] Mabeki MR. Trial of Incorporation of Cassia tora leaf flour in feed of local Senegalese Chickens: Effects on Growth Performance, Carcass Characteristics and Economic Outcome. Doctoral thesis, Cheikh Anta Diop University, Dakar. 2011; 113.

[16] Ould SMY, Azeroual E, Benazzouz B, Ouichou A, Hessni EA, Mesfioui A. Effect of a diet supplemented with phytobiotics on sexual maturity and zootechnical performance in Japanese quail (Coturnix Japonica). International Journal of Innovation and Applied Studies. 2015; 11 (2): 456-464.

[17] Jatoi AS, Sahota AW, Akram M, Javed K, Jaspal MH, Hussain J, Mirani AH, Mehmood. Effect of different body weight categories on the productive performance of four close-bred flocks of Japanese quails (Coturnix coturnix japonica). The Journal of Animal and Plant Science. 2013; 23 (1): 7-13. 
[18] Berrama Z, Mefti H, Kaidi R, Souames S. Zootechnical characterization and genetic parameters of growth performance of Japanese quail (Coturnix japonica) reared in Algeria. Livestock Research Development. 2013; 23: 3.

[19] Razafimandimby NR. Zootechnical performances of Japanese quails (Coturnix japonica) in Madagascar; case of Mada's quail farm. Higher School of Agronomic Sciences, Livestock Department, Agricultural Engineer Thesis, University of Antananarivo. 2013; 90.

[20] Ashoka A, Prabakaran R. Evaluation of growth traits in short term selection for different ages in Japanese quail. Indian Journal of Fundamental and Applied Life Sciences. 2012; 2 (1): 152 -157.

[21] Ojedapo LO, Amao SR. Sexual dimorphism on carcass characteristics of Japanase quail (Coturnix coturnix japonica) reared in derived savanna zone of Nigeria. International Journal of Science, Environment and Technology. 2014; 3 (1): 250-257.

[22] Rathert TC, Güven İ, Üçkardeş F. Sex Determination of Japanese Quails (Coturnix coturnix japonica) using with Zoometric Measurements. Turkish Journal of Agriculture - Food Science and Technology. 2017; 5 (9): $1002-1005$.

[23] Victoria O, Fayeye TR, Ayorinde LK, Olojede H. Relationship between body weight and linear body measurements in Japanese quail (Coturnix coturnix japonica). Journal of Scientific Research. 2014; 6 (1): 175-183.

[24] Siyadati SA, Irani M, Ghavidel Z. Effect of varying dietary energy to protein ratio on productive performance and carcass characteristics of Japanese quail. Annals of Biological Research. 2011; 2 (1): 149-155.

[25] Dowarah R, Sethi APS. Various dietary levels of protein and energy interaction on growth performance of white plumage of japanese quails. Veterinary World. 2014; 7 (6): 398-402.

[26] Akram M, Hussain J, Ahmad S, Rehman A, Lohani F, Munir A, Amjad R, Noshahi H. Comparative study on production performance, egg geometry, quality and hatching traits in four close-bred stocks of Japanese quail. Agriculture Advance. 2014; 3 (1): 13-18.

[27] Dahloum L, Ouaffai A, Fassih A, Milagh M, Halbouche M. Growth, laying and egg quality performance in Japanese quail (Coturnix japonica). Archivos de zootecnia. 2018; 67 (258): 168-176.

[28] Mahmood M, Rahman A, Akram M, Pasha TN, Jabbar MA. Effect of Dietary Energy Levels on Growth Performance and Feed Cost Analysis in Japanese quail. Pakistan Journal of Zoology. 2014; 46 (5): 1357-1362.

[29] Sangilimadan K, Asha R, Prabakaran R, Balakrishnan V, Murugan M. Effect of dietary protein on layer japanese quails (coturnix japonica) in tropics. Tamilnadu Journal Veterinary \& Animal Sciences. 2012; 8 (5): $271-278$.

[30] Karousa MM, Souad AA, Elaithy SM, Eman AE. Effect of housing system and sex ratio of quails on egg production, fertility and hatchability. Benha Veterinary Medical Journal. 2015; 28(2): 241-247.

[31] Moula N, Philippe FX, Ait Kaki A, Touazi L, Antoine-Moussiaux N, Leroy P. Laying and quality of quail eggs reared in semi-intensive conditions in eastern Algeria. Archivos de Zootecnia. 2014; 63(244): 693-696.

[32] Hassan HA. Variations in egg performance and plasma constituents at different ages of females Japanese quail. Egyptian Poultry Science. 2010; 30 (2): 565-581.

[33] Abdel-Azeem FAA. Influence of qualitative feed restriction on reproductive performance of Japanese quail hens. Egypt Poultry Science. 2011; 31 (4): 883-897.

[34] Marques RH, Gravena RA, Torre da Silva JD, Roccon J, Picarelli J, Hada FH, Aidar de Queiroz S, Barbosa Moraes V. M. Effect of supplementation of diets for quails with vitamins A, D and E on performance of the birds and quality and enrichment of eggs. Revista Brasileira de Zootecnia. 2011; 40 (6): 1222-1232.

[35] Genchev A. Quality and composition of Japanase quail eggs (Coturnix japonica). Trakia Journal of Sciences. 2012; 10(2): 91-101.

[36] Çabuk M, Eratak S, Alçicek A, Bozkurt M. Effects of herbal essential oil mixture as a dietary supplement on egg production in quail. The Scientific World Journal. 2014; $1-4$ 